\title{
Promotion of Ethics and Human Values through Teachings of Gautama Buddha
}

\author{
John Kanaparthy \\ Dr. T. Swarupa Rani \\ A Research Scholar, Education Research Supervisor \\ Nagarjuna University Principal of St. Josheph's college of Education for women
}

\begin{abstract}
This paper aims at presenting exemplary philosopher, Siddhartha Gautama Buddha. The Buddha who attained enlightenment under the Bodhi tree presented his philosophy as the world view of the people of the sixth century B.C. The Buddha intended his philosophy to be a practical one, aimed at the happiness of all creatures and he laid out a clear path to the goal and also observation on how to live life wisely. He taught Four Noble Truths and Eight Fold Path. These promote social ethics and individual values.
\end{abstract}

\section{INTRODUCTION}

Siddhartha Gautama Buddha was an ancient Indian philosopher and spiritual leader born in Northern India in the $6^{\text {th }}$ century BC. According to Buddha, the state should apply the moral code of society to the political and economic affairs also. The Buddha sought to evolve and propagate a social code applicable to everyone. The democratic spirit introduced in society by Buddha served as a serious blow to ideas of monarchy creeping into the Ganathantras (republics). The ideas of man, mind, society (sangha), unity and equality came alive and were blended harmoniously. Their uniqueness grew in strength and became to participate in social action. The Buddha's action plan was derived from the practical struggles in life and he preached three principles namely intelligence, compassion and equality. The teaching of the Buddha can bring about socialism through a bloodless revolution and he saw the women as equal being to the men.

\section{THE MEANING OF ETHICS AND HUMAN VALUES}

Ethics basically is a science of decimation between right and the wrong and the basic concepts and fundamental principles is decent human conduct. It includes study of universal values such as the essential equality of all men and women, human or natural rights, obedience to the law of land, concern for health and safety and, increasingly, also for the natural environment. Important and lasting beliefs or ideals shared by the members of a culture about what is good or bad and desirable or undesirable. Values have major influence on a person's behaviour and attitude and serve as broad guidelines in all situations.

\section{DHAMMAPADA}

Buddha has developed Dhammapada shapes the personality of man in the crucible of experience. It is all comprehensive, covering society, environment, individuality, the five sense organs, mind, joys and sorrows high and low, right path and peace, all of which are examined in depth. Dhammapada emits rays of light with which man can enlighten himself. It mentions rules of self-control and self-conquest to replace the practices of mutual hatred and jealousy. The tittle of Dhammapada has many meanings. One aspect of dhamma is virtue or the realisation of law. It is also characterised by noble thoughts, natural laws, rules of ethics and humanist approaches. Practice is its life breath, as it was from Buddha's own severe way of life.Dhammapada promotes human values and ethics.It was dedication for truth that had enabled him to develop as an effective teacher.

According to Buddha stability and balance of mind are highly valued as Dhammapada puts it, "By rousing himself, by earnestness, by restraint and control, the wise man may make for him-self an island which no flood can overwhelm." Buddha's Dahmmapada teaches man how to mould himself as a spokesman, as a teacher, as a preacher. He has to mould himself like an agriculturist turning the water to his fields and a carpenter shaping a bamboo into a bow. What the Buddha calls Dhamma differs fundamentally from what is called religion. Religion is related to the personal belief and Dhamma to practice. Dhamma is righteous, which means right relation between man and man in all spheres of life and social awareness. Dr B R Ambedkar saw in Dhamma an instrument to promote universal brotherhood. It is another name of it. Yet another name is morality.Analysing it further Ambedkar mentioned that purity is of three kinds, namely physical purity implying avoidance of violence, theft and leading a sinful way of life, speech purity free from falsehood, and mental purity free from laziness, inertia, excitement, and short tempter. He also said that attainment of completion of life is also Dhamma, which is possible only with the physical, verbal and mental maturity. Dhamma is opposed 
to infatuation which leads to greed for wealth which in turn leads to the fall of man. This greed also incites a man to harass other people and deserves to be discarded.

Buddha studied human problems and experience like happiness and sorrow, death and endless conflict between the different phenomena. He described his dharma as not pessimistic but enabling one to remove sorrow after recognising its existence. Its aspiration and object was to remove ignorance. TheBuddha ntroduced the idea of placing a higher value on morality and the equality of people instead of on which family or caste person is form into. This was also the first attempt to abolish discrimination and slavery in the history of mankind. Buddhism has its own long and noble tradition of scholarship and of education of the young. It has encouraged equality of social opportunity but without frantic economic competition. Buddhist values have inculcated a respect for the environment and a realistic attitude towards the importance of material things, an attitude which sees the folly of plundering and extravagantly wasting what cannot be replaced. Buddhism has not encouraged ideas of dominance of man on environment and on his fellowmen. The Buddha developed The Four Noble Truths and The Eightfold Path which promote ethics and human values, and tried to eradicate mental, physical and social short comings. Buddhist philosophy inculcates values like political and social democratic values, universal brotherhood, controlling senses, practical thinking, self-satisfaction and scientific behaviour in the classless society.

\section{The Four Noble Truths}

1. The truth of suffering (dukkha)

2. The truth of the cause of suffering (samudaya)

3. The truth of the end of suffering (nirhodha)

4. The truth of the path that frees us from suffering (magga)

Let's look at one truth at a time.

\section{The Truth of Suffering}

The First Noble Truth often is translated as "Life is suffering." Many people knew to Buddhism tune out as soon as they hear this. But the Pali word dukkha also refers to anything that is temporary, conditional, or compounded of other things. Even something precious and enjoyable is dukkha, because it will end.

Related to the nature of life is the nature of self. Are we not also temporary, conditional and compounded of many parts? We can understand that life is impermanent but are we, also, impermanent? The Buddha taught that before we can understand life and death we must understand the self.

\section{The Truth of the Cause of Suffering}

The Second Noble Truth teaches that the cause of suffering is craving or thirst (tanha). We continually search for something outside ourselves to make us happy. But no matter how successful we are, we never remain satisfied. The Buddha taught that this thirst grows from ignorance of the self. We go through life grabbing one thing after another to get a sense of security about ourselves. We attach not only to physical things, but also to ideas and opinions about ourselves and the world around us. Then we grow frustrated when the world doesn't behave the way we think it should and our lives don't conform to our expectations.

The Buddha's teachings on karma and rebirth are closely related to the Second Noble Truth.

\section{The Truth of the End of Suffering}

The Buddha's teachings on the Four Noble Truths are sometimes compared to a physician diagnosing an illness and prescribing a treatment. The first truth tells us what the illness is, and the second truth tells us what causes the illness. The Third Noble Truth holds out hope for a cure. The Buddha taught that through diligent practice, we can put an end to craving. Ending the hamster-wheel chase after satisfaction is enlightenment (bodhi, "awakened"). The enlightened being exists in a state called Nirvana.

\section{The Truth of the Path That Frees Us from Suffering}

In the Fourth Noble Truth, the Buddha as physician prescribes the treatment for our illness: The Eightfold Path. The Eightfold Path of Buddhism is the means by which enlightenment may be realized. The historical Buddha first explained the Eightfold Path in his first sermon after his enlightenment.Most of the Buddha's teachings deal with some part of the Path.

\section{The Eightfold Path is:}

1. Right View or Right Understanding, insight into the true nature of reality.

2. Right Intention, the unselfish desire to realize enlightenment.

3. Right Speech, using speech compassionately.

4. Right Action, ethical conduct; manifesting compassion.

5. Right Livelihood, making a living through ethical and non-harmful means.

6. Right Effort, cultivating wholesome qualities; releasing unwholesome qualities.

DOI: 10.9790/0837-2202020103 www.iosrjournals.org $\quad 2 \mid$ Page


7. Right Mindfulness, whole body-and-mind awareness.

8. Right Concentration, meditation or some other dedicated, concentrated practice.

The word translated as "right" is samyanc (Sanskrit) or samma (Pali), which means "wise." "wholesome," "skillful" and "ideal." It also describes something that is complete and coherent. The word "right" should not be taken as a commandment, as in "do this, or you are wrong." Another way to think of "right" in this case is in the sense of equilibrium, like a boat riding the waves and remaining "right."

\section{Practicing the Path}

The Eightfold Path is the fourth Truth of the Four Noble Truths. Very basically, the truths explain the nature of our dissatisfaction with life. The Buddha taught that we must thoroughly understand the causes of our unhappiness in order to resolve it. There is no quick fix; there is nothing we can obtain or hang on to that will give us true happiness and inner peace. What is required is a radical shift in how we understand and relate to ourselves and the world, and practice of the Path is the way to achieve that.Practice of the Path reaches into all aspects of life, every moment. It's not just something you work on when you've got time. It's also important to understand that these eight areas of practice are not separate steps to master one at a time; the practice of each part of the Path supports the other parts. The Path is divided into three main sections: wisdom, ethical conduct and mental discipline.

\section{The Wisdom Path}

Right View and Right Intention is the wisdom path. Right View is that perceiving the true nature of ourselves and the world around us. Right Intention refers to the energy and commitment.

\section{The Ethical Conduct Path}

Right Speech, Right Action and Right Livelihood are the ethical conduct path. This calls us to take care in our speech, our actions, and our daily lives to do no harm to others and to cultivate wholesomeness in ourselves.

\section{The Mental Discipline Path}

Through Right Effort, Right Mindfulness, and Right Concentration we develop the mental discipline to cut through delusion.

\section{The life of Buddha}

Buddha's original name was Siddhartha. His family belonged to the Sakya tribe of the Himalayan region. He was born in 563 B.C at Lumbini gardens in the city of Kapilavastu in the Nepal area. His father was Suddhodana, his mother Maya Devi, he was brought up his mother's sister MahaPajapathi.. His early life was luxurious and happy. He married to Yasodara at the age of sixteen in 547 B.C. and got son Rahula. Siddhartha had no clear idea of the concepts of birth, death, old age and ill health. A number of experiences made him contemplate on them. In 534 B.C. at the age of 29, he left Kapilavastu in search of the secret of these experiences, which had eluded many others before him. He left his family and kingdom as well. It was turning point in his life. Buddha's life is a vast ocean. His life and philosophy were intertwined. As many legends grow around his life, his teachings also began to take different forms.Buddha's teachings were to provide the basis for the establishment social ethics and individual values. He taught Four Noble Truths. After his enlightenment, the Buddha centred on the Four Noble Truths.

\section{CONCLUSION}

Gautama Buddha was a prophet, social revolutionist and social reformer, and a democratic political thinker. He was the greatest philosopher in the fields of morality, individual values and universal brotherhood. He was the curriculum frame worker of social behaviour.People are acting on the basis of their thoughts so the philosophy of life will be set on the principles of Buddha's philosophy. As impermanence is the main principle cause of suffering, people should understand the characteristics of nature and life with in it and try to live without getting suffering, understanding their own self. Every man should study Buddha's teachings which liberate and enlighten man to live his life in a harmonious way.

\section{REFERENCES}

[1] E. Lamotte (1988)HISTORY OF INDIAN BUDDHISM

[2] Dr.BabasahebAmbedkarWritings and Speeches - vol - II (1992) and

[3] THE BUDDHA AND HIS DHAMMA

[4] David J. Kalupahana (1994)A HISTORY OF BUDDHIST PHILOSOPHY

[5] Richard F. Gombrich (1991)sBUDDHISST PRCEPT AND PRACTICE

[6] Web surfing on Buddha and his philosophy 